This is a postprint of the following peer-reviewed publication (definitive version available at www.blackwell-synergy.com):

Scheyer TM, Anquetin J. 2008. Bone histology of the Middle Jurassic turtle shell remains from Kirtlington, Oxfordshire, England. Lethaia 41: 85-96.

\title{
Bone histology of the Middle Jurassic turtle shell remains from Kirtlington, Oxfordshire, England
}

\author{
Torsten M. Scheyer ${ }^{1,2 *}$, Jérémy Anquetin ${ }^{3}$
}

${ }^{1}$ Institute of Palaeontology, University of Bonn, Nussallee 8, D-53115 Bonn, Germany

${ }^{2}$ Current address: Paläontologisches Institut und Museum, Universität Zürich, Karl Schmid-Strasse 4, CH-8006 Zürich, Switzerland

${ }^{3}$ Department of Palaeontology, The Natural History Museum, Cromwell Road, London SW7 5BD, UK

*Corresponding author: tscheyer@pim.uzh.ch

\begin{abstract}
The Middle Jurassic (Bathonian) turtle material from the Mammal Bed at Kirtlington, Oxfordshire, England, has recently been tentatively referred to the Pleurosternidae, although the known synapomorphies of this clade were absent from the specimens. Here we present new evidence from shell bone histology that corroborates reports of pleurosternids at Kirtlington and further reveal that two different histomorphs (= two different taxa) are present in this locality. The first histomorph presents the distinctive histological structure of pleurosternids, which is described herein for the first time: the external cortical bone layers are differentiated into an inner zone of coarse, irregularly interwoven structural fibre bundles and an outer fine-fibred zone. The second histomorph has a more plesiomorphic structure and can only be assigned to Cryptodira indet. A morphological reassessment of the Kirtlington material fails to recognize two different taxa and shows that only sparse evidence supports the presence of pleurosternids in this locality. Shell bone histology thus appears as a powerful tool to study poorly preserved specimens and may in some case (like with pleurosternids) help resolve phylogenetic relationships. According to our results, the stratigraphic appearance of the Pleurosternidae is adjusted from the Kimmeridgian (Late Jurassic) to the Bathonian (Middle Jurassic), which significantly reduces the ghost lineage of Paracryptodira.
\end{abstract}


Pleurosternidae are well known from the Late Jurassic and Early Cretaceous of Western Europe and North America (e.g. Bräm 1973; Gaffney 1979a; Brinkman et al. 2000; Milner 2004), and may be also present in the Late Cretaceous and Early Palaeocene of North America (Hutchison \& Holroyd 2003). Together with the exclusively North American Baenidae they form the monophyletic Paracryptodira, the sister group of the Eucryptodira (the clade containing the crown-group cryptodires). The Pleurosternidae primarily include the two genera Glyptops and Pleurosternon (= Mesochelys Evans \& Kemp 1975). Based on an association of skull and shell, Brinkman et al. (2000) included Dinochelys whitei Gaffney (1979a) (Late Jurassic, USA) into the Pleurosternidae. Gaffney (1979a) noted similarities between Dinochelys and Desmemys Wegner, 1911 (Early Cretaceous, Germany), and Brinkman et al. (2000) expressly included Desmemys within the Pleurosternidae. Hutchison (1987) proposed a possible relationship of Compsemys Leidy, 1856 with the Pleurosternidae, but it is only recently that cranial material was associated with the type species Compsemys victa (Hutchison \& Holroyd 2003).

Pleurosternidae are mainly supported by a single synapomorphy, which is the absence of medial contact between the pterygoids that allows the basisphenoid to contact the vomer (Gaffney 1979a, 1996; Gaffney \& Meylan 1988; Joyce 2007). In addition, the presence of an anterior projection of the frontals that partly separates the nasals medially is also considered a synapomorphy of pleurosternids (Joyce 2007). Paracryptodira (Pleurosternidae + Baenidae) are supported by three synapomorphies: (1) the reduction of the prefrontal exposure on the dorsal surface of the skull; (2) a reduced fenestra perilymphatica; and (3) a secondary reduction of the supraoccipital crest (Joyce 2007). The clade Paracryptodira was originally based on the location of the foramen posterius canalis carotici interni (fpcci) halfway along the suture between the basisphenoid and the pterygoid (Gaffney 1975). Two contradictory scenarios are still currently debated regarding the evolution of this character (Jamniczky et al. 2006): some authors interpret the position of the fpcci in paracryptodires as ancestral regarding the condition seen in eucryptodires (Evans \& Kemp 1976; Rieppel 1980; Joyce 2007), whereas others think that the position of the fpcci evolved independently from the same primitive condition in both paracryptodires and eucryptodires (Gaffney 1975, 1996; Brinkman \& Nicholls 1993). However, in the current state of knowledge, a fpcci placed halfway along the basisphenoid-pterygoid suture is a synapomorphy of Paracryptodira + Dorsetochelys delairi Evans \& Kemp, 1976 (Joyce 2007, p. 27).
The Middle Jurassic turtle material from the UK was regularly referred to the pleurosternids, although often without convincing support. The turtle known as Protochelys Lydekker, 1889 from the Bathonian Stonesfield Slate was placed within the pleurosternids (e.g. Bergounioux 1955; Romer 1956, 1966), but a reassessment of the material shows that this turtle could either be a stem turtle, a basal pleurodire or a basal cryptodire (Anquetin 2007). Turtle remains from the Kilmaluag Formation (Bathonian), Isle of Skye, Scotland, were also referred to the pleurosternids (Savage 1984); however, we found this assignment to be incorrect and ongoing research suggests that this turtle may be a stem taxon (J. Anquetin, personal observation). Finally, the turtle material from the Bathonian microvertebrate locality of Kirtlington, Oxfordshire, was described by Gillham (1994) and tentatively assigned to the Pleurosternidae, although the aforementioned synapomorphies of pleurosternids are not preserved on the specimens. The purpose of this paper is to present new results from bone histology that allow Gillham's (1994) referral to be tested.

This study is part of a larger project on the bone microstructures of fossil and recent turtle shells (Scheyer in press). Based on a comprehensive and representative sampling, characteristic microstructures were found to be apomorphic for certain turtle clades (Scheyer \& SánchezVillagra 2007; Scheyer et al. 2007). It was found that Pleurosternidae share a unique shell bone histology. In a first step, thin-sections of Glyptops plicatulus from the Late Jurassic Morrison Formation, Wyoming, USA, Compsemys sp. from the Early Palaeocene of the Hell Creek Formation, Montana, USA, and Pleurosternidae indet. from the Late Jurassic of the Guimarota Coal Mine, Portugal, are described to illustrate the characteristic bone histology of pleurosternid shells. In a second step, the pleurosternid shell microstructures are compared with those of samples from the Bathonian locality of Kirtlington. In a third step, the anatomy of the Kirtlington remains is reassessed in light of the new bone histological data.

\section{Material and Methods}

To analyse the shell bone histology, standard petrographic thin-sections were prepared of the bone samples. The nomenclature of shell elements follows Zangerl (1969), and the histological descriptions are mainly based on Francillon-Vieillot et al. (1990), Scheyer \& Sánchez-Villagra (2007), and Scheyer et al. (2007). The terms 'costal' and 'pleural', which both occur extensively in the literature, are treated as synonymous. The terms 'external' and 'internal' are used throughout the text 
instead of 'dorsal' and 'ventral' to prevent confusion between dorsal carapacial and ventral plastral bones of the turtle shell (e.g., the 'dorsal' surface of a carapace bone corresponds to the external surface of the bone, whereas the 'dorsal' surface of a plastral bone corresponds to the visceral surface of the bone). The term 'interior' refers to the core or centre of the shell bone (i.e., cancellous bone) that is usually framed by the external and internal cortex.

\section{Glyptops plicatulus (Cope, 1877)}

The studied specimens of $G$. plicatulus were found in Quarry 9, Como, Wyoming, USA (Morrison Formation, Late Jurassic). The sample comprises a neural (YPM 57160), a medial part of a costal (YPM 57161), a costal (YPM 57162), a peripheral (YPM 57163), and a plastron fragment (hyo- or hypoplastron, YPM 57164). The external surface of the shell elements is sculptured with low vermiculate ridges and tubercles framed by elongate low ridges extending perpendicular to the plate margins.

\section{Compsemys sp.}

The material of Compsemys sp. derives from the Early Palaeocene part of the Hell Creek Formation, McCone County, Montana, USA. A neural (UCMP V90077/ 150197), two costals (UCMP V90077/150195; UCMP V90077/150196), a peripheral (UCMP V87192/150199), and a plastron fragment (hyo- or hypoplastron; UCMP V87192/150198) are included. The external surface of the shell bones is sculptured with low small tubercles that occasionally form short low ridges. At the margins, isolated tubercles fuse to form parallel short ridges that extend perpendicular to the sutures of the bones. It is noteworthy that the sculpturing pattern of these samples is generally fainter than that of G. plicatulus.

\section{Pleurosternidae gen. et sp. indet}

Three specimens come from the Kimmeridgian (Late Jurassic) beds of the Guimarota Coal Mine near Leiria, Portugal (e.g. Bräm 1973; Gassner 2000). These include a costal (GUI-CHE-53), the medial part of a costal (GUICHE-54) and a plastron fragment (hyo- or hypoplastron; GUI-CHE-55). Furthermore, two specimens, a neural (IPFUB P-Barkas-20) and a peripheral (IPFUB P-Barkas-21), from the Late Jurassic (Tithonian-?Berriasian) alluvial fan deposits of Porto das Barcas, Lourinhã, Portugal, were sampled. The external surface of the neural is weathered and strongly pitted. The external surface of the other shell elements is sculptured with low vermiculate ridges and tubercles framed by low ridges extending perpendicular to the plate margins. The internal surface of all shell elements is smooth.

\section{Kirtlington turtle shell material}

The fragmentary turtle shell material was found in the Kirtlington Cement Quarry (Mammal Bed, 3p layer of McKerrow et al. 1969), Bathonian (Middle Jurassic), Kirtlington, Oxfordshire, UK. The sample includes six small shell fragments (IPB R583 to 589) that could only be tentatively assigned to a location on the shell (i.e., carapace or plastron fragment). One of the shell bone fragments has a sculptured external surface (IPB R586), which is, based on its weathered state, not diagnostic. The other fragments appear to have fairly smooth external surfaces, but the material is also strongly weathered.

\section{Taxa used for comparison}

The external cortex structure of the aforementioned species has been compared with that of the following cryptodires: aff. Naomichelys sp. (FM PR 273, TMP 90.60.07, TMP 2000.16.01; Solemydidae), Basilemys sp. (FM P27371, TMP 80.08.296, TMP 2003.12.278, YPM 9703; Nanhsiungchelyidae); cf. Aspideretoides sp. (IPB R533a-e; Trionychidae); Rupelchelys breitkreutzi (SMNS 87218; Cheloniidae sensu lato); Xinjiangchelys chowi (SGP 200134a-c; Xinjiangchelyidae) and Xinjiangchelys sp. (SGP 2002/4a-d; Xinjiangchelyidae). Note that the phylogenetic position of Solemydidae is still unclear (Danilov 2005).

\section{Abbreviations}

BMNH, The Natural History Museum, London, UK; FM, Field Museum, Chicago, Illinois, USA; IPB, GoldfussMuseum, Institute of Paleontology, University of Bonn, Germany; IPFUB, Institut für Geowissenschaften [formerly Institut für Paläontologie], Freie Universität Berlin, Germany; GUI-CHE, Testudinate material from Guimarota Coal Mine currently housed in the collections of the Institut für Geowissenschaften - Fachrichtung Paläontologie, Freie Universität Berlin, Germany (material will be finally deposited in the collections of the Servicio Geológico de Portugal, Lisboa (Geological Survey of Portugal, Lisbon)); SMNS, Staatliches Museum für Naturkunde, Stuttgart, Germany; SGP, Sino-German Project, material currently housed at the Institute and Museum of Geology and Palaeontology, University of Tübingen, Germany; TMP, Royal Tyrrell Museum of Palaeontology, Drumheller, Canada; UCMP, Museum of Paleontology, University of California at Berkeley, California, USA; YPM, Peabody Museum of Natural History at Yale University, New Haven, Connecticut, USA. 

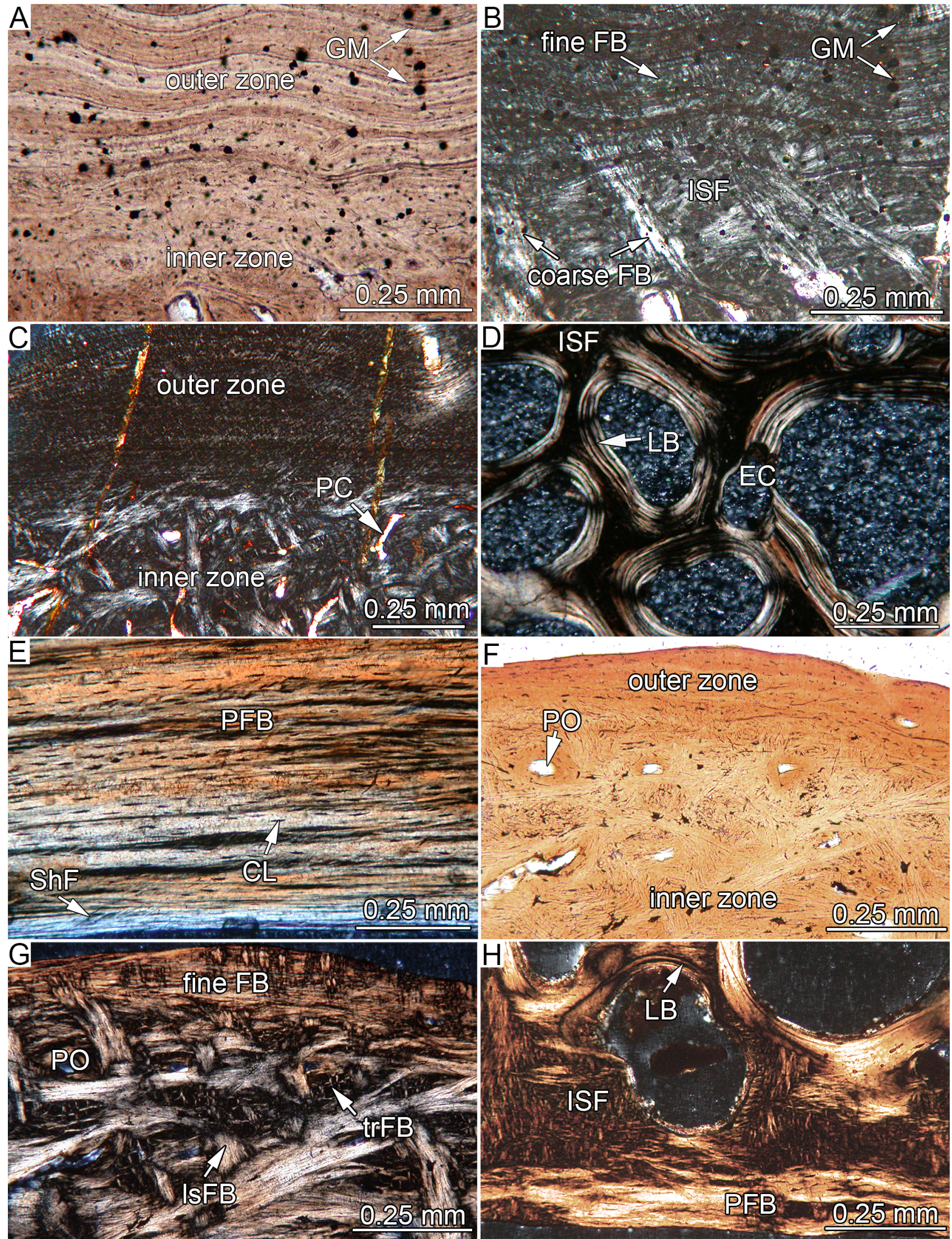
Figure 1 (previous page) - Shell bone histology of pleurosternid turtle taxa (A-E) and Kirtlington histomorph I (F-H). A, B. Closeup of the external cortex of the peripheral (YPM 57163) of Glyptops plicatulus. A. Normal transmitted light. B. Polarized light. The more external zone of the external cortex is fine-fibred and growth marks are clearly visible, while the more internal zone is coarse-fibred and almost completely lacks growth marks. C. Close-up of the two external cortical zones of peripheral IPFUB P-Barkas 21 of Pleurosternidae gen. et sp. indet. in polarized light. D. Close-up of the interior cancellous bone of the plastron fragment (YPM 57164) of G. plicatulus in polarized light. E. Detail of the internal cortex of costal UCMP V90077/150195 of Compsemys sp. in polarized light. Note Sharpey's fibres inserting into the parallel-fibred bone. F, G. Close-up of the external cortex of the carapace fragment IPB R586. F. Normal light. G. Polarized light. $\mathrm{H}$. Detail of the transition from interwoven structural fibre bundles to parallel-fibred bone in the internal cortex of shell fragment IPB R583 in polarized light. Abbreviations: CL, bone cell lacunae; EC, erosion cavity; FB, fibre bundle; GM, growth mark; ISF, interwoven structural collagenous fibre bundles; LB, lamellar bone; IsFB, longitudinally sectioned fibre bundle; PC, primary vascular canal; PFB, parallel-fibred bone; PO, primary osteon; ShF, Sharpey's fibres; trFB, transversely sectioned fibre bundle.

\section{Bone histology of pleurosternid turtles}

The bone histology of G. plicatulus, Compsemys sp., and Pleurosternidae gen. et sp. indet. from Guimarota and Porto das Barcas is very similar and is thus described in one section. Variations among taxa are stated where appropriate. All three taxa share a diploe makeup of the shell, with well-developed external and internal cortices framing interior cancellous bone.

\section{External cortex}

The external cortex of the shell elements of all three taxa is formed by a thick layer of compact bone. The cortical bone has a regular, wavy external surface because of the regular external ornamentation pattern of the bone. Few foramina are present in the bone tissue at the interstitial areas adjacent to the vermiculate low ridges and tubercles. The bone tissue consists of interwoven structural collagenous fibre bundles, and can be divided into two zones (Fig. 1A-C). The more external zone is less vascularized and it is dominated by fine interwoven structural fibre bundles. The second, more internal zone has higher levels of vascularization and it is characterized by coarse, irregularly interwoven structural fibre bundles. These fibre bundles can differ significantly in length and diameter. The thickness of the more external zone compared to the more internal zone varies among the taxa and is strongly dependent of surface preservation. Growth marks are present throughout the external cortex; however, they become more diffuse and cannot be distinguished in the more internal zone. Growth marks are seen as highly birefringent lines in polarized light in Compsemys sp. but appear as dark lines in G. plicatulus and Pleurosternidae gen. et sp. indet. from Portugal. Besides the aforementioned foramina, the more external zone of the external cortex is mainly avascular, whereas the more internal zone is characterized by few scattered primary osteons and short and round primary vascular canals. Additionally, reticular primary vascular canal patterns can be developed.

\section{Cancellous bone}

The cancellous bone constitutes short and thick bone trabeculae and mostly vascular spaces of small to medium size (generally between 0.2 and $1.0 \mathrm{~mm}$ in diameter, Fig. 1D). Towards the sutured margins of the plates, vascular spaces are often slightly externointernally flattened and elongated. Larger vascular spaces of circular or irregular shape are found in the proximal parts of the sampled peripheral and in the costal fragments (YPM 57161 to 57163) of G. plicatulus. Whereas a few erosion cavities lack secondary lamellar bone, the majority of the walls of the bone trabeculae constitute lamellar bone. Primary interstitial bone is preserved in most trabecular branching spots, besides the very thin trabeculae of the sampled peripheral of G. plicatulus.

\section{Internal cortex}

The internal cortex is well developed but generally thinner than the external cortex. In G. plicatulus and Compsemys sp., the internal cortex is usually avascular. However, small scattered primary vascular canals (mostly ranging between 0.01 and $0.04 \mathrm{~mm}$ in diameter) can be present in the location of the incorporated rib of the costal elements. In the sample of Pleurosternidae gen. et sp. indet. from Portugal, the internal cortex can be weakly vascularized with primary vascular canals. In G. plicatulus, the internal cortex constitutes homogenous and ordered layers of parallel fibred bone. In Compsemys sp. (Fig. 1E) and Pleurosternidae gen. et sp. indet. from Portugal, the fibre bundles of the parallel-fibred bone are coarser and vary in extension and orientation, giving the bone tissue a less ordered appearance. Sharpey's fibres can be visible as fibres or fibre bundles that extend perpendicular or in angles into the parallel-fibred bone matrix.

\section{Sutures}

Sutures are generally well developed in the sampled pleurosternid turtles. Growth marks, which are deflected from the external cortex, can be distinguished in the bone tissue of the sutures, thus showing an increasing sutural relief during ontogeny. Fibre bundles that extend 
perpendicular to the sutural margin of the plate are common.

\section{Variation}

A unique form of bone tissue erosion and bone deposition was observed in the plastron fragment of $G$. plicatulus (YPM 57164). First, within the larger erosion cavities, secondary lamellar bone was deposited centripetally. Second, small circular or semicircular spaces (mostly ranging between 0.05 and $0.1 \mathrm{~mm}$ in diameter) occur in the lamellae of the lamellar bone. Third, at the margins of the larger cavities new bone deposition seems to occur around the circular or semicircular spaces. This phenomenon of bone erosion and deposition, which so far has not been found in the remainder of the sampled turtles, needs to be further studied before any hypothesis to its development can be made.

\section{Bone histology of the Kirtlington turtle shell elements}

Two histomorphs are found among the Kirtlington samples. However, the small fragmentary pieces of shell do not show any external morphological characteristics that would allow a differentiation of these histomorphs.

\section{Histomorph I}

Histomorph I is represented by six specimens (IPB R583 to 588). This histomorph essentially presents the same bone histology than that described above for pleurosternid turtles so only a short summary is provided here.

Internal and external cortical bone layers are well developed, framing an area of interior cancellous bone. The interwoven structural collagenous fibre bundles of the external cortex are divided into a more external fine-
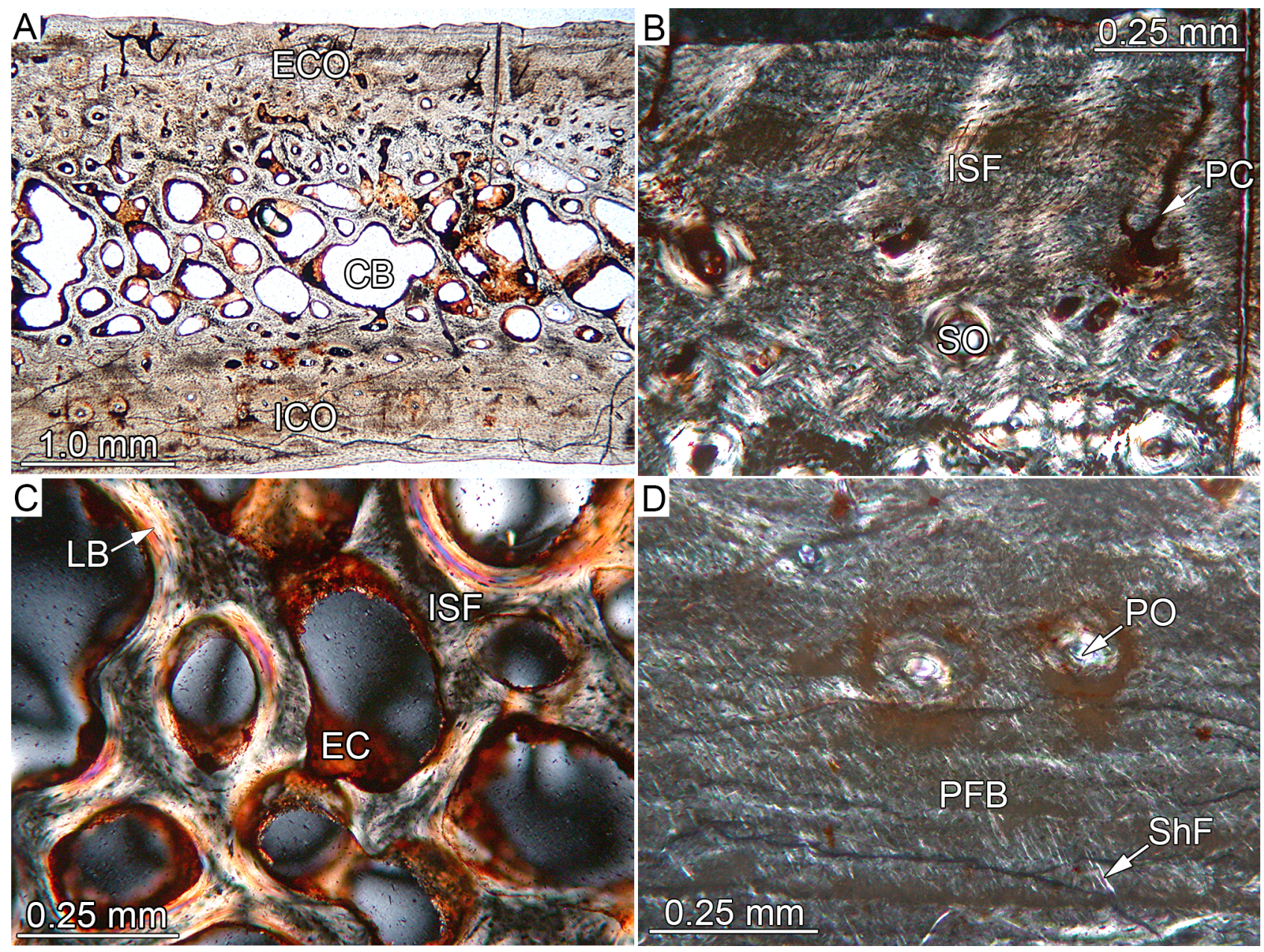

Figure 2 - Shell bone histology of Kirtlington histomorph II. A. Section of a plastron fragment (IPB R589; hyo- or hypoplastron) in normal light. Note the well-developed diploe structure. B. Close-up of the external cortex of the bone showing interwoven structural fibre bundles in polarized light. C. Close-up of the interior cancellous bone of the former specimen in polarized light. D. Detail of the parallelfibred matrix and Sharpey's fibres of the internal cortical bone in polarized light. Abbreviations: CB, cancellous bone; EC, erosion cavity; ECO, external cortex; ICO, internal cortex; ISF, interwoven structural collagenous fibre bundles; LB, lamellar bone; PC, primary vascular canal; PFB, parallel-fibred bone; PO, primary osteon; ShF, Sharpey's fibres; SO, secondary osteons. 
fibred zone and a more internal coarse-fibred zone (Fig. $1 F, G)$. Growth marks are best visible in the fine-fibred zone. The external cortex is weakly vascularized. The cancellous bone consists of short and thick primary trabeculae lined with secondary lamellar bone. The internal cortex is slightly thinner than the external cortex. The internal cortex consists of parallel-fibred bone (Fig. 1H). A transitional zone is present where the primary interwoven structure that makes up most of the internal cancellous bone meets and interdigitates with the parallel-fibred bone tissue of the internal cortex. The cortical bone is weakly vascularized, but scattered erosion cavities extend internally from the transitional zone.

\section{Histomorph II}

Histomorph II is represented only by a single specimen (IPB R589) and shows fundamental differences from histomorph I and the pleurosternids described above. The external and internal cortices in the shell bone of histomorph II are well developed and of equal thickness (Fig. 2A). Based on its fragmentary condition, no suture zones are preserved in the specimen.

\section{External cortex}

The external cortex is composed of interwoven structural collagenous fibre bundles, which have a homogeneous distribution of fibre bundles that extend perpendicular, subparallel and oblique to the external surface of the bone (Fig. 2B). The bone tissue is mainly vascularized by primary osteons and primary vascular canals. Many of the canals open onto the external surface of the bone. Growth marks are present but become too diffuse to be distinguished from other structures of the bone tissue.

\section{Cancellous bone}

The transition between the external cortex and the cancellous bone is not clearly defined because of the amount of scattered secondary osteons and erosion cavities. The interior cancellous bone consists of short but overall slender bone trabeculae and cavities of small to moderate size (ranging between 0.1 and $1.0 \mathrm{~mm}$ in diameter; Fig. 2C). The vascular cavities are round to irregular shaped. Many of the trabeculae still retain primary bone tissue (i.e., interwoven structural collagenous fibre bundles), but are mostly lined with secondary lamellar bone.

\section{Internal cortex}

The internal cortex consists of parallel-fibred bone (Fig. 2D). Fibre bundles that extend at oblique angles into the parallel-fibred bone (i.e., Sharpey's fibres) are present. The bone tissue is weakly vascularized by scattered primary osteons and few primary vascular canals. The internal-most layers of the cortical bone are avascular.

\section{Reassessment of the Kirtlington material}

Kirtlington is a microvertebrate locality and available turtle remains are quite fragmented, which prevents any comprehensive anatomical study. This material was first studied by Gillham (1994), who provided a description of the best-preserved specimens. Gillham (1994) tentatively assigned the Kirtlington turtle to the Pleurosternidae based on a combination of characters, which did not include any of the pleurosternid synapomorphies. Based on the external morphology it is impossible to differentiate two taxa as revealed by the bone histology. However, now that the presence of pleurosternids at Kirtlington is further supported by bone histological data, a review of both the material and Gillham (1994)'s arguments is needed.

BMNH R12404 (fig. 2A, B in Gillham 1994) is a medial fragment of costal showing a costal-costal contact in midline (i.e., absence of neural). As noted by Gillham (1994), such a contact is sometimes observed in Pleurosternon bullockii (e.g. BMNH 28618). However, a medial contact of costals associated with the absence of neurals is also observed in numerous pleurodires and trionychoids (Meylan and Gaffney 1989; Joyce 2007). According to Gillham (1994, p. 585), only about a third of peripheral plates from Kirtlington bear scale sulci and, when present, they usually run perpendicular to the edge of the carapace (= peripheral-peripheral sulci). This suggests that marginal scales are wider than peripheral plates and overlap the costal plates, which is a characteristic known in $P$. bullockii, G. plicatulus and $D$. whitei (Gaffney 1979a; Milner 2004). However, a similar overlapping of the marginals onto costals has also been signalled for some trionychoids (Meylan \& Gaffney 1989) and xinjiangchelyids (Peng \& Brinkman 1993; Hirayama et al. 2000). Gillham (1994, p. 586) stated that the mesoplastra of the Kirtlington turtle met in midline ( $a$ rather primitive feature), but this cannot be verified as the only known specimen is in a private collection and is not figured. BMNH R12407 (fig. 3C in Gillham 1994) is a complete kite-shaped entoplastron that is longer than wide. This morphology is different from that commonly found in pleurosternids (Gaffney 1979a; Milner 2004) where the entoplastron is either wider than long ( $P$. bullockii) or as wide as long (G. plicatulus, Pleurosternon portlandicum). However, this specimen clearly presents a characteristic surface ornamentation of low vermiculate ridges and tubercles framed by fine linear striations perpendicular to the plate margins. This ornamentation is specific of $G$. plicatulus, P. bullockii and the baenid 
Trinitichelys hiatti (Gaffney 1979a). Overall, the presence of that ornamentation on numerous specimens is the best argument in favour of the presence of pleurosternids at Kirtlington.

As the bone histology suggests that at least two species of turtle are present at Kirtlington, the reconstruction of the skull proposed by Gillham (1994, fig. 6) might be composite. Indeed, only isolated skull bones are known from this locality. One of Gillham's (1994) strongest argument in favour of an assignment to pleurosternids is the presence of reduced prefrontal lappets, which is now considered a paracryptodire synapomorphy (Joyce 2007). No prefrontal is known from Kirtlington, but Gillham (1994, fig.7A-D) identified two fragments of frontal: BMNH 12414 and BMNH 12415. If the latter was correctly identified as a posterior part of frontal, the former was misinterpreted as the anterior part of the frontal. According to Gillham (1994), BMNH 12414 shows that the prefrontal lappets of the Kirtlington turtle were reduced, as in paracryptodires. However, this specimen is reinterpreted here as a fragment of postorbital: its internal surface presents a strong ridge that delimits the posterior margin of the fossa orbitalis, no such ridge is known on the frontal. Then, the presence of small prefrontal lappets cannot be demonstrated with available remains.

As observed by Gillham (1994), some cranial remains show a very small or absent involvement of the jugal in the orbit. BMNH 12419 (fig. 8C, D in Gillham 1994) is a nearly complete left postorbital that presents a long anteroventral process along the orbit margin, which could prevent the contact of the jugal with the orbit. Additionally, BMNH 12418, an almost complete jugal (Gillham 1994, fig. 8A, B), lacks a clearly defined orbital
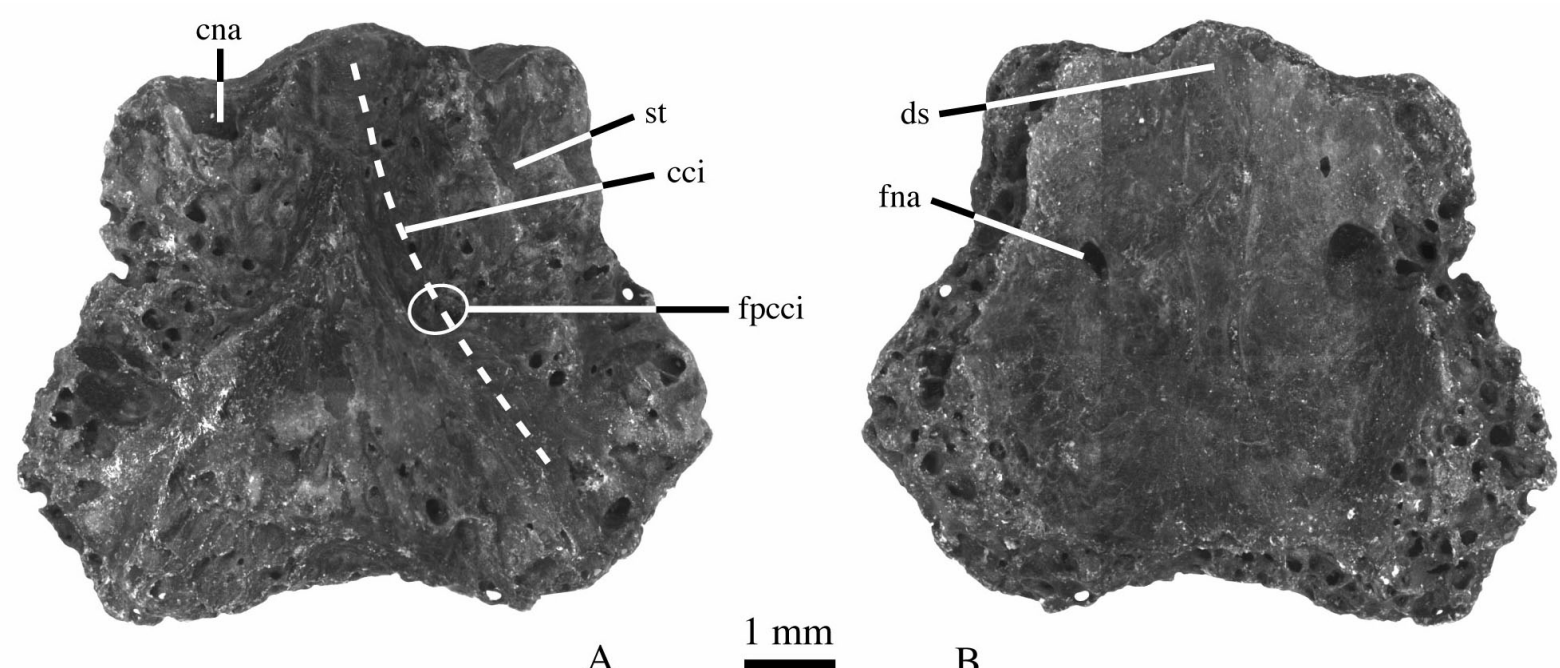

A

$1 \mathrm{~mm}$

B
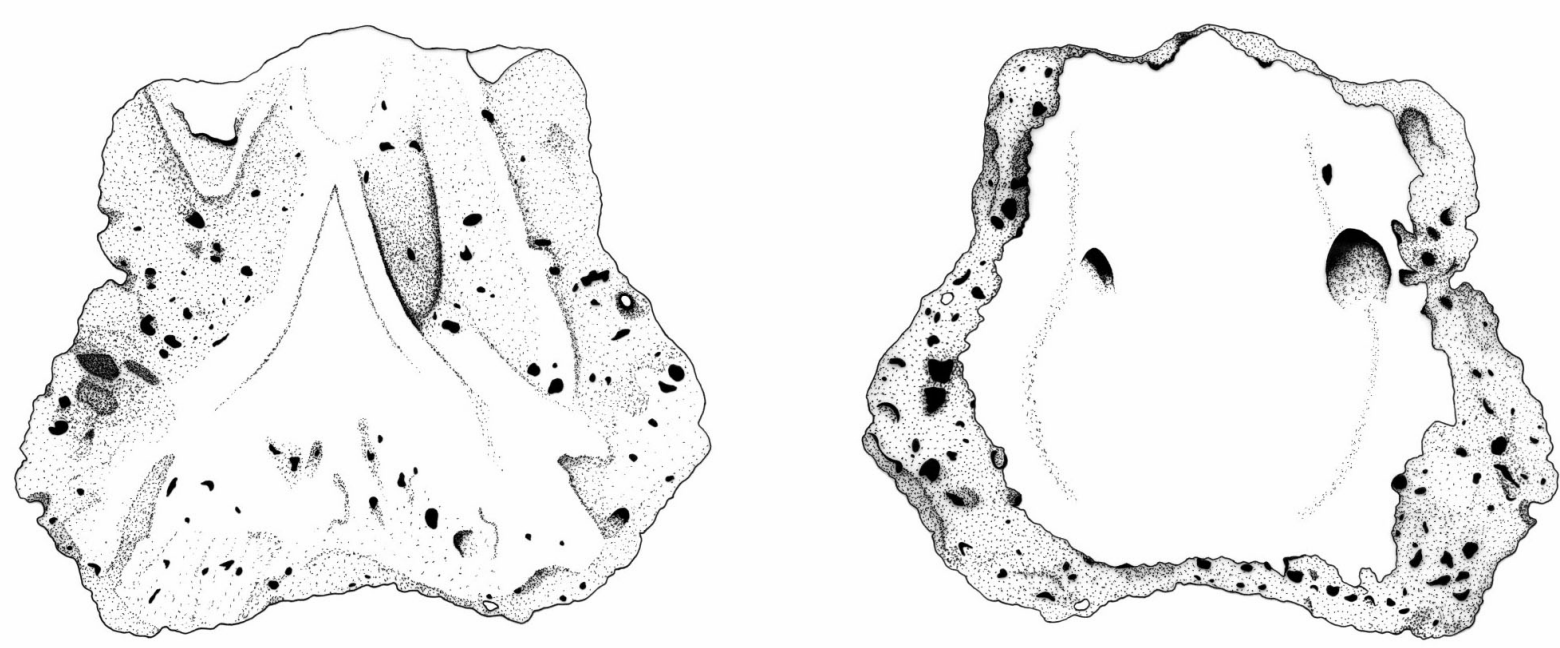

Figure 3 - BMNH R16498, partial basisphenoid, Kirtlington Quarry, Bathonian, Oxfordshire, England. A. Ventral view. B. Dorsal view. Anterior upward. Abbreviations: cna, canalis nervi abducentis; cci, canalis caroticus internus; ds, dorsum sellae; fna, foramen nervi abducentis; fpcci, foramen posterius canalis carotici interni; st, sutural contact with the pterygoid. Dashed line: path of the internal carotid artery. 
border between the postorbital and the maxillary facets. The curved orbital border described by Gillham (1994, p. 589) on this specimen is actually limited to the medial process of the jugal and probably covered externally by the contact between maxilla and postorbital. Both Pleurosternon (= Mesochelys Evans \& Kemp, 1975) and G. plicatulus have a jugal that is excluded from the orbit by an anterior contact between the postorbital and the maxilla (Gaffney 1979a). The morphology of $D$. whitei is unclear (Brinkman et al. 2000). Such a contact between the maxilla and the postorbital excluding the jugal from the orbit is uncommon among turtles, but it is also known in the baenid Eubaena cephalica, the basal paracryptodire Arundelemys dardeni and at least three extant species: Platysternon megacephalum, Emys orbicularis and Malayemys subtrijuga (Gaffney 1979b; Lipka et al. 2006). The phylogenetic repartition of this character should be subjected to scrutiny. However, for the period of time considered (Jurassic and Early Cretaceous), it is only known in paracryptodires and could be seen a possible evidence of their presence at Kirtlington.

BMNH R16498 (Fig. 3) is a partial turtle basisphenoid from Kirtlington recently added to the BMNH collections. The posterior part is missing and anteriorly the bone is broken at the level of the dorsum sellae. The ventral surface shows the sutural contact with the two pterygoids and it is obvious that the latter meet anteriorly to the basisphenoid preventing it from contacting the vomer (Fig. 3A). In other words, this specimen lacks the main pleurosternid synapomorphy (see above). A wide groove running along the basisphenoid-pterygoid suture on both sides indicates the passage of the internal carotid artery. This groove is divided into two parts. Anteriorly, the groove is deeper and deepens anteromedially. This part corresponds to the canalis caroticus internus where the internal carotid artery penetrates the basisphenoid and enters the cavum cranii at the posterior end of the sella turcica. Posteriorly, the groove is only a shallow marking on the ventral surface of the basisphenoid and is more ventral than the basisphenoid-pterygoid suture, which indicates that the internal carotid artery is not floored ventrally on this part and simply runs on the ventral surface of the basicranium. The limit between the anterior and the posterior part of the groove marks the position of the foramen posterius canalis carotici interni (Fig. 3A). Hence, the fpcci opens along the basisphenoidpterygoid suture in a configuration known only in paracryptodires (see above).

\section{Discussion}

A separation of the external cortical bone into two distinct zones is common, e.g. in Pleurosternidae (see Fig.
1), Trionychidae, Solemydidae (aff. Naomichelys sp.), and Basilemys sp. (present study, Fig. 4; Scheyer in press). However, the distinct separation into a more external fine-fibred zone and a more internal zone that is composed of irregularly coarse fibre bundles is characteristic only for Pleurosternidae. Basilemys sp. (Fig. 4A, B), Solemydidae (Fig. 4C, D), and Trionychidae (Fig. 4E; Scheyer et al. 2007), show unique characteristics of their own in the external cortex that separate them from Pleurosternidae (Scheyer in press).

Based on the bone histology, two different turtle taxa appear to be present in the sample from Kirtlington. Histomorph I (IPB R-583 to 588) has a characteristic internal zone of thick, coarse irregular fibre bundles and a more external fine-fibred zone incorporated into the external cortex of the bone. Such an external cortex structure is only found in Pleurosternidae. In $R$. breitkreutzi from the Oligocene of Germany (Karl \& Tichy 1999) and Xinjiangchelys spp. from the upper Middle Jurassic of China (e.g. Matzke et al. 2005), the only other turtles where coarse fibres dominate the external cortex (Scheyer in press), a more external, fine-fibred zone is not developed at all (Fig. 4F-H). One might assume that a purportedly outer, finer fibred layer might have been eroded and is thus a taphonomic artefact. However, this is opposed by the fact that in all specimens of Rupelchelys breitkreutzi (five specimens, all SMNS 87218) and Xinjiangchelys spp. (seven specimens, SGP 2001/34a-c, SGP 2002/4a-d) a fine-fibred outer zone is consistently lacking, with many of these specimens showing wellpreserved bone surfaces. It is thus most plausible that the Kirtlington histomorph I represents a member of the Pleurosternidae. As such, the fossil record of the group would be extended from the Late Jurassic back into the Middle Jurassic.

Kirtlington Histomorph II (IPB R-589), with its homogeneous arrangement of short and equally fine fibre bundles, has a bone microstructure found in many taxa of different groups and thus reflects mainly plesiomorphic characters. Based on its shell bone histology, the material cannot be assigned beyond Cryptodira incertae sedis.

Based on the anatomy, it is not possible to recognize several turtle taxa at Kirtlington. A review of the available material shows that little anatomical evidence supports the presence of pleurosternids in this locality. Overall, the best evidence is the presence of the peculiar shell ornamentation found in Glyptops, Pleurosternon and Compsemys on numerous specimens from Kirtlington. Cranial remains suggest the presence of a postorbitalmaxilla contact excluding the jugal from the orbit. During the Jurassic and Early Cretaceous, this characteristic is 

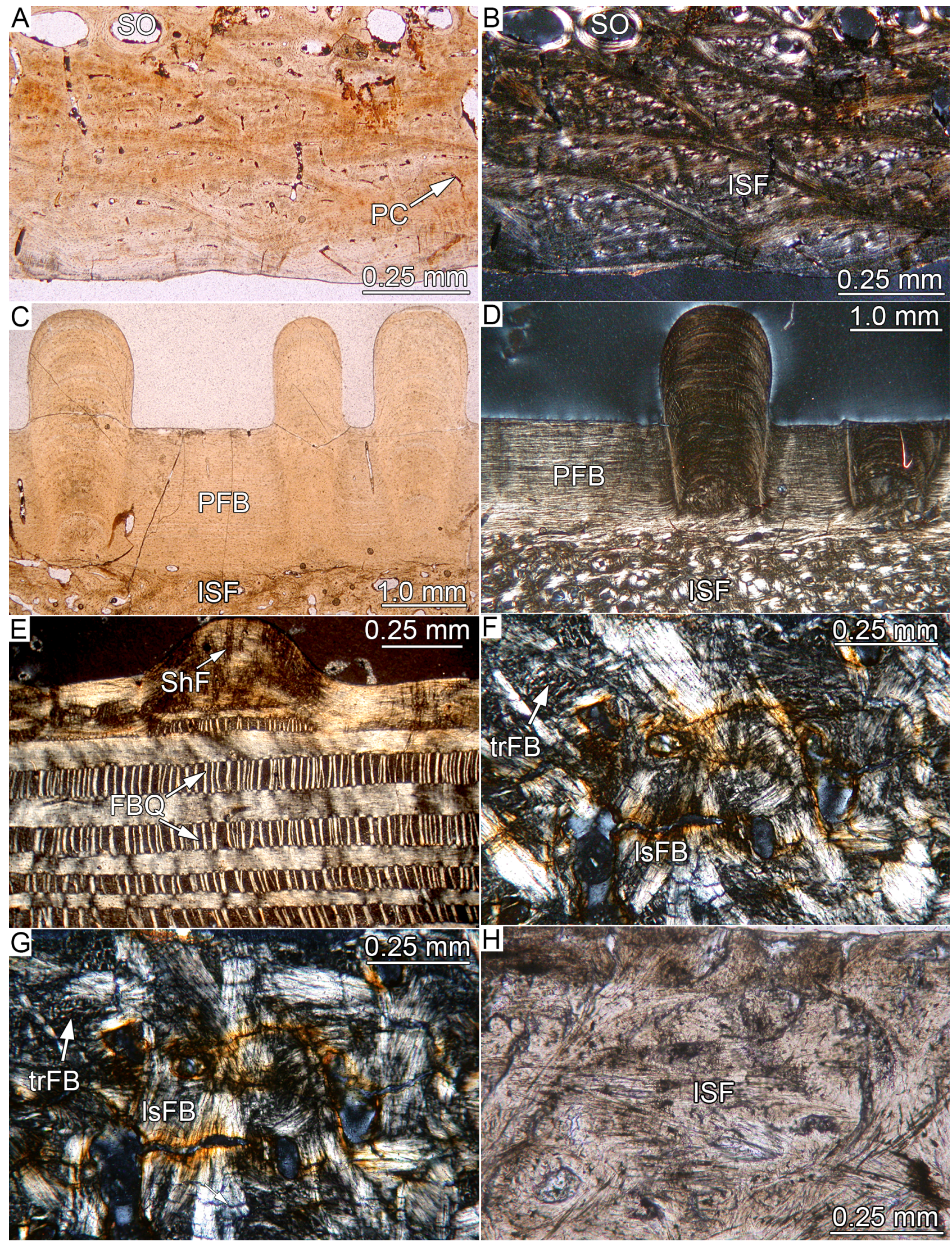
Figure 4 (previous page) - Close-ups on the external cortices of outgroups used in comparison to Pleurosternidae. A, B. In Basilemys sp. (YPM 9703), the external cortex is dominated by a spindle-shaped pattern of the interwoven structural fibre bundles, which is closely linked to the heavily sculptured surface ornamentation of the bone. A. Normal transmitted light. B. Polarized light. C, D. Although the external cortex has separate inner and outer zones in Solemydidae aff. Naomichelys sp. (TMP 90.60.07), the outer zone is characterized by highly distinctive ornamental tubercles and columns. C. Normal transmitted light. D. Polarized light. E. In trionychid turtles (e.g. IPB R533a), the external cortex is dominated by a highly organized pattern of stacked fibre bundles plies. F. Close-up of the cortical bone of $R$. breitkreutzi (SMNS 87218) showing longitudinal and transverse sections of the coarse interwoven fibre bundles in polarized light. Note set of structural fibre bundles running obliquely to the external bone surface. G. Same section as in F, but rotated about $45^{\circ}$ under polarized light. Note second set of structural fibre bundles extending mainly parallel and perpendicular to the external surface of the bone. H. Section of Xinjiangchelys chowi (SGP 2001-34a) showing the coarse interwoven structural fibre bundles in normal transmitted light. Abbreviations: FBQ, fibre bundle quandrangles; ISF, interwoven structural collagenous fibre bundles; IsFB, longitudinally sectioned fibre bundle; PC, primary vascular canal; PFB, parallel-fibred bone; ShF, Sharpey's fibres; SO, secondary osteons; trFB, transversely sectioned fibre bundle.

mainly, if not only, found in paracryptodires: i.e., Pleurosternon (= Mesochelys Evans and Kemp 1975), G. plicatulus, E. cephalica and A. dardeni (Gaffney 1979a, b; Lipka et al. 2006), which suggests the presence of paracryptodires at Kirtlington. This conclusion is confirmed by a new isolated basisphenoid (BMNH R16498, Fig. 3), in which the foramen posterius canalis carotici interni opens along the basisphenoid-pterygoid suture. Although this specimen strongly supports a referral to the Paracryptodira (Fig. 5), it also tends to prevent a referral to the pleurosternids by the probable absence of a basisphenoid-vomer contact and the presence of pterygoids meeting in midline (Joyce 2007). This specimen can either support the presence of a nonpleurosternid paracryptodire beside the pleurosternid identified by shell histology, or, if this specimen pertains to the pleurosternid species, suggest that the basisphenoid-vomer contact of pleurosternids appeared later than their specific bone histology during evolution.
However, in the current state of knowledge, it is not possible to favour one or the other of these two hypotheses.

\section{Conclusions}

The present and related studies (Scheyer in press; Scheyer \& Sánchez-Villagra 2007; Scheyer et al. 2007) indicate that the bone microstructure of turtle shells is valuable for assessing phylogenetic hypotheses. One asset of this method is clearly the possibility to include poorly known and poorly preserved fossil specimens into analyses. Shell bone histology corroborates an assignment to the Pleurosternidae in the case of the Kirtlington histomorph I, when the morphological study fails to find convincing evidence. This study, by confirming the previous conclusions of Gillham (1994), extends the fossil record of pleurosternids from the Late Jurassic back in the Middle Jurassic (Bathonian; see Fig. 5). Although the

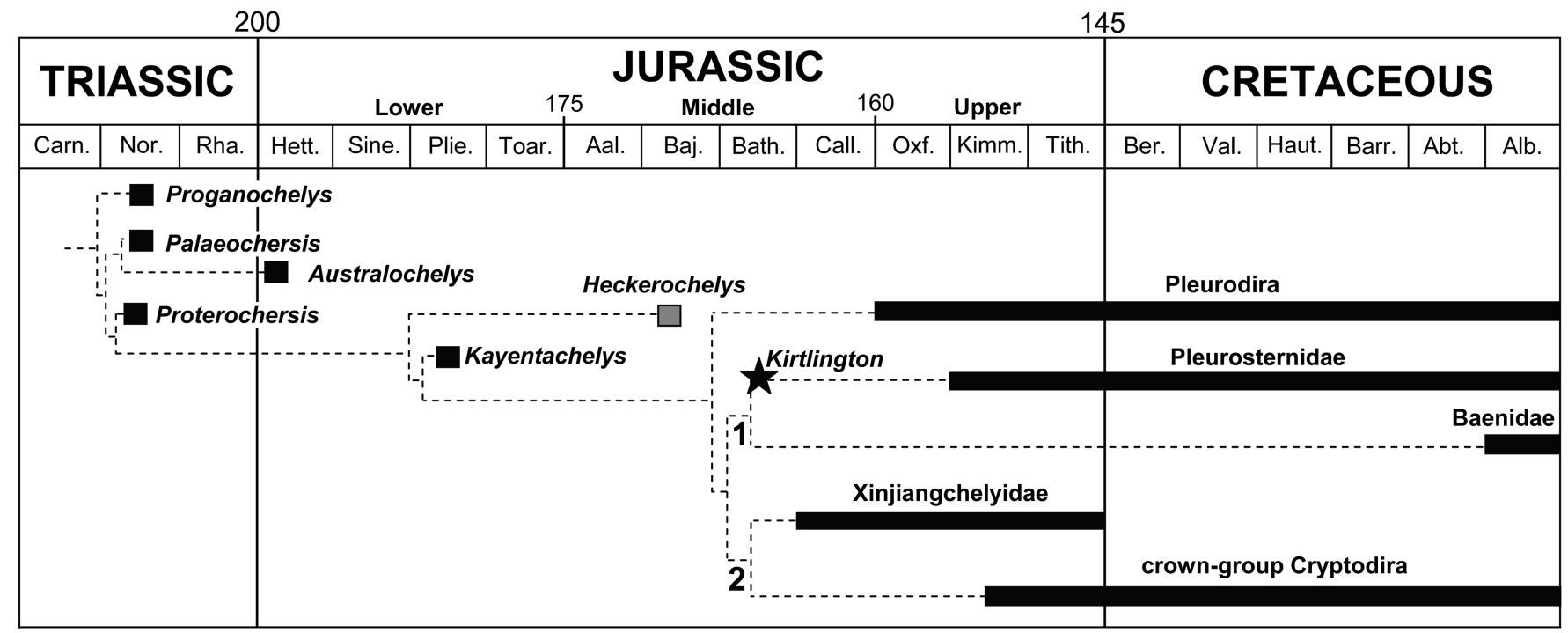

Figure 5 - New stratigraphic occurrence of Pleurosternidae (phylogeny based on Rougier et al. 1995; Sukhanov 2006; Joyce 2007; age estimates modified after Gradstein \& Ogg 2004). Based on the samples of the Kirtlington locality (asterisk) studied herein, the base of the stratigraphical range of Pleurosternidae shifts from the Late Jurassic (Kimmeridgian) to the Middle Jurassic (Bathonian), thus significantly shortening the ghost-lineage of paracryptodires. Note that the exact stratigraphical age of Heckerochelys Sukhanov, 2006, is not precisely known (Middle Jurassic, but no later than Bathonian), thus its position is tentatively marked in gray. Abbreviations: 1 , Paracryptodira; 2, Eucryptodira. 
presence of paracryptodires in the Middle Jurassic was already phylogenetically suggested by the presence of eucryptodires (xinjiangchelids and chengyuchelyids) in the Middle Jurassic of Asia (e.g. Nessov 1995; Tong et al. 2002; Matzke et al. 2005), the Kirtlington material represents the first evidence of that presence.

Acknowledgements. - We thank Susan Evans and Marc Jones (London), Pat Holroyd and Howard Hutchison (Berkeley), Walter Joyce (New Haven), Jim Gardner (Drumheller), Olivier Rieppel (Chicago), Ronald Bötcher (Stuttgart), Andreas Matzke and Michael Maisch (Tübingen), and Thomas Gassner (Berlin), for kindly providing the material for the study. Sandra Chapman (BMNH, London) is thanked for access to the Kirtlington material. Olaf Dülfer (Bonn) is thanked for his help in preparing the thin-sections. Two anonymous reviewers are thanked for improving the manuscript. This study was funded by DFG grant no SA-469/15.

\section{References}

Anquetin, J. 2007: A new (stem?) turtle from the Middle Jurassic of Skye, Scotland. Journal of Vertebrate Paleontology 27 (Supplement to No. 3), 41A.

Bergounioux, F.M. 1955: Testudinata. In Piveteau, J. (ed.): Traité de Paléontologie 5, 487-544. Masson et Cie, Paris.

Bräm, H. 1973: Chelonia from the Upper Jurassic of Guimarota mine (Portugal). Contribuição para o conhecimento da Fauna do Kimeridgiano da Mina de Lignito Guimarota (Leiria, Portugal) III Parte, VII-Memorias dos Servicos geológicos de Portugal, (nova Sér) 22, 135141.

Brinkman, D.B. \& Nicholls, E.L. 1993: The skull of Neurankylus eximius (Testudines: Baenidae) and a reinterpretation of the relationships of this taxon. Journal of Vertebrate Paleontology 13, 273-281.

Brinkman, D.B., Stadtman, K. \& Smith, D. 2000: New material of Dinochelys whitei Gaffney, 1979, from the Dry Mesa Quarry (Morrison Formation, Jurassic) of Colorado. Journal of Vertebrate Paleontology 20, 269-274.

Cope, E.D. 1877: On reptilian remains from the Dakota beds of Colorado. Proceedings of the American Philosophical Society 17, 193-196.

Danilov, I.G. 2005: Die fossilen Schildkröten Europas. In Fritz, U. (ed.): Handbuch der Reptilien und Amphibien Europas Band 3/IIIB: Schildkröten (Testudines) II, 329-441. Aula-Verlag, Wiebelsheim, Germany.
Evans, J. \& Kemp, T.S. 1975: The cranial morphology of a new Lower Cretaceous turtle from southern England. Palaeontology 18, 25-40.

Evans, J. \& Kemp, T.S. 1976: A new turtle skull from the Purbeckian of England and a note on the early dichotomies of cryptodire turtles. Palaeontology 19, 317324.

Francillon-Vieillot, $H_{\text {., }}$ de Buffrénil, V., Castanet, J., Géraudie, J., Meunier, F.J., Sire, J.Y., Zylberberg, L. \& de Ricqlès, A. 1990: Microstructure and mineralization of vertebrate skeletal tissues. In Carter, J.G. (ed.): Skeletal Biomineralization: Patterns, Processes and Evolutionary Trends, 471-530. Van Nostrand Reinhold, New York.

Gaffney, E.S. 1975: A phylogeny and classification of the higher categories of turtles. Bulletin of the American Museum of Natural History 155, 387-436.

Gaffney, E.S. 1979a: The Jurassic turtles of North America. Bulletin of the American Museum of Natural History 162, 93- 135.

Gaffney, E.S. 1979b: Comparative cranial morphology of recent and fossil turtles. Bulletin of the American Museum of Natural History 164, 65-375.

Gaffney, E.S. 1996: The postcranial morphology of Meiolania platyceps and a review of the Meiolaniidae. Bulletin of the American Museum of Natural History 229, $1-166$.

Gaffney, E.S. \& Meylan, P.A. 1988: A phylogeny of turtles. In Benton, M.J. (ed.): The Phylogeny and Classification of the Tetrapods. Volume 1: Amphibians, Reptiles, Birds, 157-219. Clarendon Press, Oxford.

Gassner, T. 2000: The turtles from the Guimarota mine. In Martin, T. \& Krebs, B. (eds): Guimarota-A Jurassic Ecosystem, 55-58. Dr. Friedrich Pfeil, München, Germany.

Gillham, C. 1994: A fossil turtle (Reptilia: Chelonia) from the Middle Jurassic of Oxfordshire, England. Neues Jahrbuch der Geologie und Paläontologie. Monatshefte 10, 581-596.

Gradstein, F.M. \& Ogg, J.G. 2004: Geological Time Scale 2004 - Why, how, and where next! Lethaia 37, 175-181.

Hirayama, R., Brinkman, D.B. \& Danilov, I.G. 2000: Distribution and biogeography of non-marine Cretaceous turtles. Russian Journal of Herpetology 7, 181-198.

Hutchison, J.H. 1987: New cranial material of Compsemys (Testudines) and its systematic implications. Journal of Vertebrate Paleontology 7(Supplement to No. 3), 19A.

Hutchison, J.H., \& Holroyd, P.A. 2003: Late Cretaceous and early Paleocene turtles of the Denver Basin, 
Hutchison, J.H., \& Holroyd, P.A. 2003: Late Cretaceous and early Paleocene turtles of the Denver Basin, Colorado. Rocky Mountain Geology 38, 121-142.

Jamniczky, H.A., Brinkman, D.B. \& Russell, A.P. 2006: Phylogenetic implications of the turtle cranial circulation: a review. In Danilov, I.G. \& Parham, J.F. (eds): Fossil Turtle Research, Vol. 1. Russian Journal of Herpetology 13(Suppl.), 84-92.

Joyce, W.G. 2007: Phylogenetic relationships of Mesozoic turtles. Bulletin of the Peabody Museum of Natural History 48, 3-102.

Karl, H.-V. \& Tichy, G. 1999: Zur Taxonomie eines neuen Tribus von Seeschildkröten aus dem Oligozän von Deutschland (Testudines: Chelonioidea). The taxonomy of a new tribe of sea-turtles from the Oligocene of Germany (Testudines: Chelonioidea). Joannea-Geologie und Paläontologie 1, 61- 77.

Leidy, J. 1856: Notices of extinct Vertebrata discovered by Dr. F. V. Hayden, during the expedition to the Sioux country under command of Lieut. G. K. Warren. Proceedings of the Academy of Natural Sciences of Philadelphia 8, 311-312.

Lipka, T.R., Therrien, F., Weishampel, D.B., Jamniczky, H.A., Joyce, W.G., Colbert, M.W. \& Brinkman, D.B. 2006: A new turtle from the Arundel Clay facies (Potomac Formation, Early Cretaceous) of Maryland, U.S.A. Journal of Vertebrate Paleontology 26, 300-307.

Lydekker, R. 1889: Catalogue of the fossil Reptilia and Amphibia in the British Museum (Natural History)-Part 3. The Order Chelonia. Trustees of the British Museum, London.

Matzke, A.T., Maisch, M.W., Sun, G.E., Pfretzschner, H.U. \& Stöhr, H. 2005: A new Middle Jurassic xinjiangchelyid turtle (Testudines; Eucryptodira) from China (Xinjiang, Junggar Basin). Journal of Vertebrate Paleontology 25, 6370.

McKerrow, W.S., Johnson, R.T. \& Jakobson, M.E. 1969: Palae- oecological studies in the Great Oolite at Kirtlington, Oxfordshire. Palaeontology 12, 56-83.

Meylan, P.A. \& Gaffney, E.S. 1989: The skeletal morphology of the Cretaceous cryptodiran turtle, Adocus, and the relationships of the Trionychoidea. American Museum Novitates 2941, 1- 60.

Milner, A.R. 2004: The turtles of the Purbeck Limestone Group of Dorset, southern England. Palaeontology 47, $1441-1467$.

Nessov, L.A. 1995: On some Mesozoic turtles of the Fergana Depression (Kyrgyzstan) and Dzhungar Alatau
Ridge (Kazakhstan). Russian Journal of Herpetology 2, 134-141.

Peng, J.-H. \& Brinkman, D.B. 1993: New material of Xinjiangchelys (Reptilia: Testudines) from the Late Jurassic Qigu Formation (Shishugou Group) of the Pingfengshan locality, Junggar Basin, Xinjiang. Canadian Journal of Earth Sciences 30, 2013- 2026.

Rieppel, O. 1980: The skull of the Upper Jurassic cryptodire turtle Thalassemys, with a reconsideration of the chelonian braincase. Palaeontographica, Abt. A 171, 105-140.

Romer, A.S. 1956: Osteology of the Reptiles. 772 pp. University of Chicago Press, Chicago.

Romer, A.S. 1966: Vertebrate Paleontology, 3rd edition, 468 pp. University of Chicago Press, Chicago.

Rougier G.W., De La Fuente, M.S. \& Arcucci A.B. 1995: Late Triassic turtles from South America. Science 268, 855- 858 .

Savage, R.J.G. 1984: Mid Jurassic mammals from Scotland. In Reif, W.-E. \& Westphal, F. (eds): Third Symposium on Mesozoic Terrestrial Ecosystems, Short Papers, 210-213. Attempto Verlag, Tübingen, Germany.

Scheyer, T.M. in press: Comparative bone histology of the turtle shell (carapace and plastron): implications for turtle systematics, functional morphology and turtle origins. Unpublished PhD Thesis, Institute of Palaeontology, University of Bonn.

Scheyer, T.M. \& Sánchez-Villagra, M.R. 2007: Carapace bone histology in the giant pleurodiran turtle Stupendemys geographicus: phylogeny and function. Acta Palaeontologica Polonica 52, 137-154.

Scheyer, T.M., Sander, P.M., Joyce, W.G., Böhme, W. \& Witzel, U. 2007: A plywood structure in the shell of fossil and living soft-shelled turtles (Trionychidae) and its evolutionary implications. Organisms Diversity \& Evolution 7, 136-144.

Sukhanov, V.B. 2006: An archaic turtle, Heckerochelys romani gen. et sp. nov., from the Middle Jurassic of Moscow region, Russia. Fossil Turtle Research, Vol 1, Russian Journal of Herpetology 13(Suppl.), 112-118.

Tong, H., Buffetaut, E. \& Suteethorn, V. 2002: Middle Jurassic turtles from southern Thailand. Geological Magazine 139, 687-697.

Wegner, T. 1911: Desmemys bertelsmanni n. g. n. sp. Ein Beitrag zur Kenntnis der Thalassemydidae Rütimeyer. Palaeontographica 58, 105-132.

Zangerl, R. 1969: The turtle shell. In Gans, C. Bellairs, A.d'A. \& Parsons, T. S. (eds): Biology of the Reptilia. Vol. 1 Morphology A, 311-339. Academic Press, London. 